\title{
Anurans of a remnant of Mixed Rainforest in southern Brazil
}

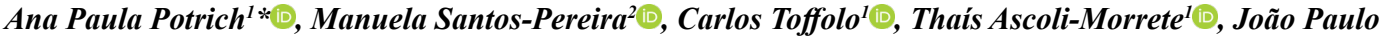 \\ Soares $^{3} \mathbb{B}$ \& Noeli Zanella ${ }^{1} \mathbb{C}$ \\ ${ }^{1}$ Universidade de Passo Fundo, Programa de Pós-Graduação em Ciências Ambientais, 99001-970, São José, \\ Passo Fundo, RS, Brasil. \\ ${ }^{2}$ Universidade do Estado do Rio de Janeiro, Departamento de Ecologia, Programa de Pós-graduação em \\ Ecologia e Evolução, Rio de Janeiro, RJ, Brasil. \\ ${ }^{3}$ Universidade de Passo Fundo, Instituto de Ciências Biológicas, 99001-970 Passo Fundo, RS, Brasil. \\ *Corresponding author: Ana Paula Potrich, e-mail: 131516@upf.br
}

POTRICH, A.P., SANTOS-PEREIRA, M., TOFFOLO, C., ASCOLI-MORRETE, T., SOARES, J.P., ZANELLA, N. Anurans of a remnant of Mixed Rainforest in southern Brazil. Biota Neotropica 20(4): e20201091. https:// doi.org/10.1590/1676-0611-BN-2020-1091

\begin{abstract}
The Brazilian Atlantic Forest is one of the world's most biodiverse biomes, with large numbers of endemic and threatened species. However, this biome has suffered extensive deforestation and habitat fragmentation, with a drastic reduction of its original vegetation cover. The compilation of data on the occurrence patterns of anurans and their natural history is important for the development of effective conservation strategies. Here, we present the results of a survey of the anuran fauna of Parque Estadual do Papagaio Charão (PEPC) in Rio Grande do Sul state, southern Brazil, providing information on species endemism, conservation status, and reproductive modes. We collected data on the local anurans between March 2018 and February 2019 using active searches and pitfall traps. We recorded 26 anuran species distributed in seven families, with eight different reproductive modes. The largest number of species (20) was found at the forest edge, followed by the interior of the forest and open area, each with 16 species. The most abundant species were Leptodactylus plaumanni (41.7\% of records), Physalaemus cuvieri (27.1\%), and P. carrizorum (16.5\%). Greater species richness and abundance were recorded during the rainier months, while temperature influenced only the abundance of the anurans. Rhinella henseli, Rhinella icterica, Vitreorana uranoscopa, Aplastodiscus perviridis, Boana curupi, Boana leptolineata and Proceratophrys brauni are all endemic to the Atlantic Forest. Melanophryniscus devincenzii is classified as Endangered by the IUCN, and Proceratophrys bigibbosa as Near Threatened. Boana curupi is considered to be Endangered in Rio Grande do Sul state, and Vulnerable in Brazil, while V. uranoscopa is Near Threatened in Rio Grande do Sul. Our findings emphasize the importance of protected areas, such as the PEPC, for the maintenance of anuran populations and communities in the Mixed Rainforest formations of southern Brazil.
\end{abstract}

Keywords: Atlantic Forest; species list; community structure; reproductive modes; seasonality; conservation.

\section{Anuros de um remanescente de Floresta Ombrófila Mista no sul do Brasil}

Resumo: A Mata Atlântica abriga a maior biodiversidade do planeta, com elevados números de endemismos e espécies ameaçadas de extinção. Entretanto, esse bioma tem sofrido extensa perda e fragmentação do habitat, com redução drástica da sua cobertura vegetacional original. Suprir lacunas sobre a história natural e os padrões de ocorrências de anuros auxiliam no desenvolvimento de estratégias de conservação para esse grupo. Neste estudo apresentamos a anurofauna do Parque Estadual do Papagaio Charão (PEPC), no estado do Rio Grande do Sul, sul do Brasil, com informações sobre endemismos, status de conservação e modos reprodutivos das espécies. Nossas amostragens em campo ocorreram entre março de 2018 e fevereiro de 2019 e utilizamos procura ativa e pitfalls traps para a coleta dos anuros. Registramos 26 espécies de anuros distribuídas em sete famílias e oito modos reprodutivos. Um número maior de espécies foi encontrado na borda (20 espécies), seguida da floresta e área aberta (16 espécies cada). As espécies mais abundantes foram Leptodactylus plaumanni (41,7\%), Physalaemus cuvieri $(27,1 \%)$ e $P$. carrizorum $(16,5 \%)$. Maior riqueza e abundância foram registradas no período com maior pluviosidade e a temperatura influenciou somente a abundância dos anuros. Rhinella henseli, R. icterica, Vitreorana uranoscopa, Aplastodiscus perviridis, Boana curupi, B. leptolineata e Proceratophrys brauni são endêmicas da Mata Atlântica. Melanophryniscus devincenzii está classificada como "Em perigo" e Proceratophrys bigibbosa como "Quase ameaçada" pela IUCN. 
Boana curupi é considerada "Em perigo" no estado do Rio Grande do Sul e "Vulnerável" no Brasil. Vitreorana uranoscopa consta como "Quase ameaçada" no Rio Grande do Sul. Nossos resultados mostram a importância de áreas protegidas, como o PEPC, para a manutenção das populações e comunidades de anuros da Floresta Ombrófila Mista. Palavras-chave: Mata Atlântica; lista de espécies; estrutura da comunidade; modos reprodutivos; sazonalidade; conservação.

\section{Introduction}

The considerable biodiversity and endemism of the Brazilian Atlantic Forest, combined with its extensive deforestation, has resulted in the extensive decimation of this biome, with only $11.7 \%$ of the original vegetation now remaining (Ribeiro et al. 2009). Ecological processes are altered in human-modified landscapes due to the progressive reduction in the size and quality of remnant areas of natural vegetation, which provokes changes in both biotic and abiotic factors, such as resource availability and temperature (Saunders et al. 1991, Laurence 2008). Habitat fragmentation degrades these ecosystems continuously, reducing the occurrence of species, the richness of communities, and the dispersal of both fauna and flora (Haddad et al. 2015). In southern Brazil, the Mixed Rainforest is an Atlantic Forest formation characterized by the presence of the gymnosperm Araucaria angustifolia (Bertol.) Kuntze., (Oliveira-Filho et al. 2013). This forest formation has been widely devastated, with the remnants now surviving in protected areas, either in the private domain or on private land (Sonego et al. 2007)

Anuran amphibians may be influenced directly or indirectly by anthropogenic impacts in a number of different ways, due in particular to the physiological characteristics of these animals, such as their moist and permeable skin, and the features of their life cycle (Wells 2007), with habitat loss being considered the principal factor responsible for the worldwide decline in anuran populations (Blaustein \& Kiesecker 2002, Whittaker et al. 2013). The principal factors contributing to this threat include the loss, degradation, and fragmentation of habitats, edge effects, and the influence of the surrounding matrix (Becker et al. 2007, Almeida-Gomes \& Rocha 2014, Schneider-Maunoury et al. 2016, Pfeifer et al. 2017, Ferrante et al. 2017, Ribeiro et al. 2018).

A total of 7,245 anuran amphibian species are currently recognized, worldwide (Frost 2020), of which, 1,093 are known to occur in Brazil (Segalla et al. 2019), that is, $15.1 \%$ of the total number. More than half (625 species or $57.2 \%$ ) of Brazilian anurans are found in the Atlantic Forest, and most ( 485 or $77.6 \%$ ) of these species are endemic to this biome (Rossa-Feres et al. 2017). The Mixed Rainforest is home to 109 species of anurans, and 26 (24\%) are endemic to this formation (Rossa-Feres et al. 2017).

The anuran amphibian community has been the focus of many studies in Brazil (e.g. Martins et al. 2014, Leivas \& Hiert 2016, Santos-Pereira et al. 2016, Andrade et al. 2017, Ceron et al. 2017, Silva et al. 2018, Foerster \& Conte 2018, Fiorillo et al. 2018). Surveys typically provide important insights into the characteristics of an anuran community and its populations (Rocha et al. 2003). The compilation of a list of the species present in a given area is an essential first step in the development of effective conservation measures (Toledo \& Batista 2012, Vasconcelos et al. 2014). More detailed studies, including the influence of environmental heterogeneity (Silva et al. 2012, Santos \& Conte 2014) or the variation in climate, on anuran diversity (Costa et al.
2012, Titon \& Gomes 2015, Vasconcelos \& Nascimento 2016), provide increasingly valuable insights into the ecology of anuran communities.

In the present study, we investigate the species richness, spatial distribution (forest edge, interior, and open area), and the seasonal variation in the characteristics of an anuran community in a remnant of the Mixed Rainforest formation of the southern Atlantic Forest of Brazil.

\section{Materials and Methods}

\section{Study area}

Our study was conducted in the Parque Estadual do Papagaio Charão - PEPC (2754'49” S, 52 48'52”'W, 503 m a.s.1.), located in the municipality of Sarandi, in northern Rio Grande do Sul state, southern Brazil, which is part of the Upper Uruguay physiogeographic region. This state park has an area of 1,000 hectares, and is representative of the Mixed Rainforest phytophysiognomy (SEMA 2020) of the Atlantic Forest biome (Figure 1). The region's climate is subtropical humid, $C f a$ in the Köppen-Geiger classification system. The mean annual temperature is $19.4^{\circ} \mathrm{C}$ and mean annual rainfall is $1,765 \mathrm{~mm}$ (Wrege et al. 2012).

\section{Sampling methods}

We collected anurans using two methods. One method was active searching (Crump \& Scott-Jr 1994), during which at least two collectors surveyed transects at night (18-23h) during three consecutive days per month (except in June and July). For this, we used two preexisting transects located within the three different environments sampled forest edge, interior, and open area. We searched carefully for anurans along each transect, examining bromeliads, the leaf litter, tree trunks, rocks, marshes, streams, ponds, floodplains, and other habitats. A total of 459 hours of active searching was conducted during the present study, including 144 hours in the forest edge, 180 hours in the forest interior, and 135 hours in the open area.

The second method was pitfall trapping using interception traps interconnected by drift-fences (Corn 1994). These traps were used in pairs, with one set being deployed at the edge of the PEPC forest fragment $\left(27^{\circ} 54^{\prime} 50^{\prime \prime} \mathrm{S}, 52^{\circ} 48^{\prime} 57^{\prime \prime} \mathrm{W}\right)$ and the other in its interior (27 $54^{\prime} 49^{\prime}$ ' S, 52 $\left.49^{\circ} 21^{\prime \prime} \mathrm{W}\right)$. Each set of traps consisted of two straight lines of $40 \mathrm{~m}$ in length, separated by a distance of $30 \mathrm{~m}$. The two sets of traps were separated by a distance of at least $500 \mathrm{~m}$, in an attempt to avoid spatial autocorrelation. Each trap line consisted of five plastic 60-L buckets, which were buried in the ground and connected by a 60 $\mathrm{cm}$-tall drift fence. Overall, 12 buckets were deployed in each habitat type. We perforated the bucket bottoms to permit rainwater runoff. We opened the pitfall traps on four consecutive days each month for 12 months, with a total of 48 days of sampling between March 2018, and February 2019, which is the equivalent of 1,152 bucket-days. 

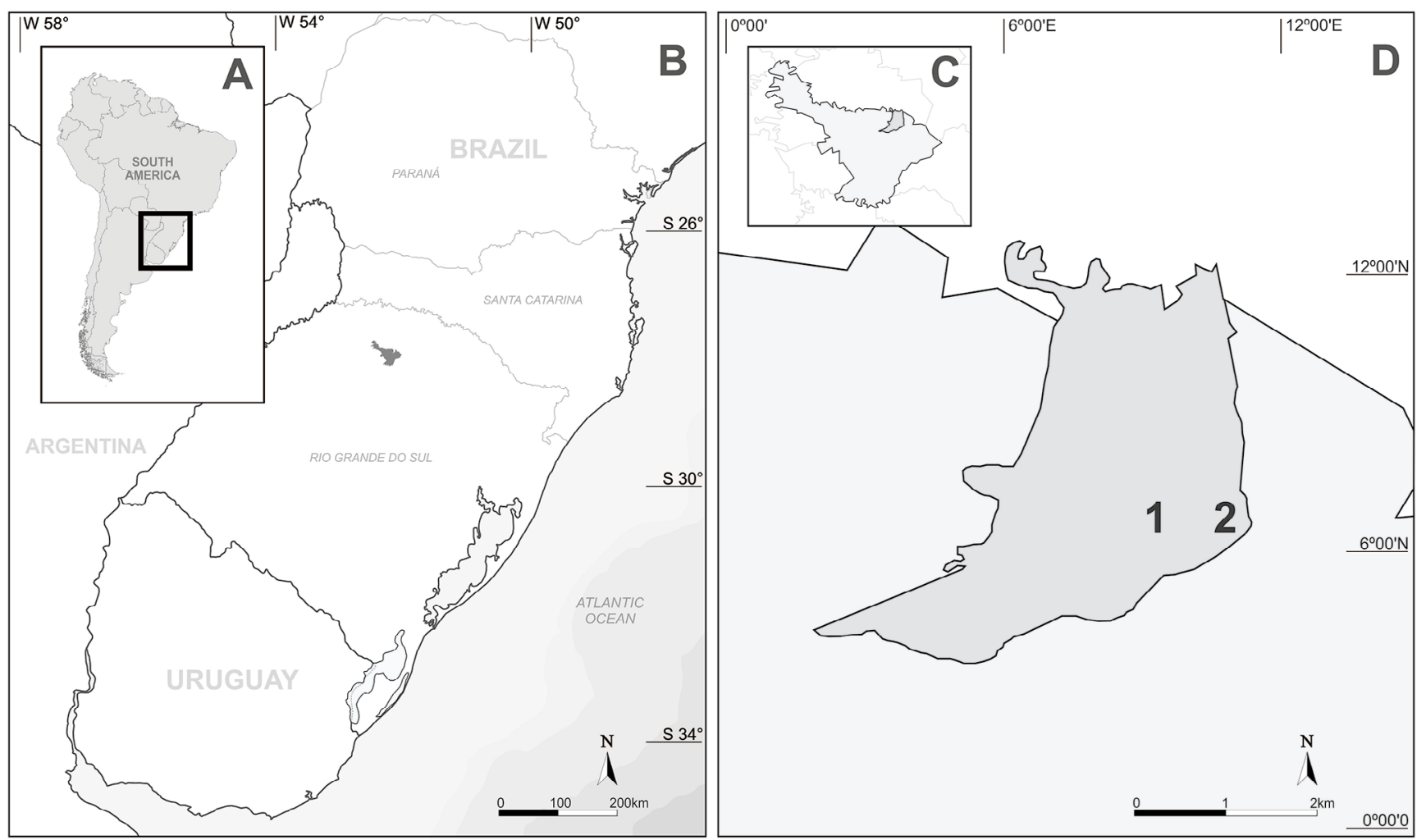

Figure 1. Location of the pitfall traps in the Parque Estadual do Papagaio Charão, in the municipality of Sarandi, Rio Grande do Sul, Brazil: 1 - forest interior; 2 - forest edge.

The traps were checked daily during sampling, and when not in use, the traps were sealed off, to avoid the unintentional capture, and potential death, of terrestrial vertebrates.

We collected the abiotic data (temperature, humidity, and rainfall) using a thermo-hygrometer and digital pluviometer, which were installed in the PEPC. We deposited voucher specimens in the Amphibian Collection of the University of Passo Fundo, CAUPF, under permits SISBIO no. 26826-1; SEMA/RS no. 49/2017; CEUA no. 11/2018 (Appendix 1). We also considered previous records of anuran species in the PEPC obtained by the team of the UPF Herpetology Laboratory (unpublished data).

\section{Data analysis}

We evaluated the sampling efficiency using a rarefaction curve, based on the matrix of the monthly records of anuran species (one sample $=$ one day) by both active searches and the pitfall traps. We ran the nonparametric Bootstrap estimator in EstimateS9.0 (Colwell 2013) with 1,000 randomizations.

Prior to the statistical analyses, the data were tested to verify the satisfaction of the assumptions of normality and homoscedasticity of variances (Zuur et al. 2010). We used the $t$ test to determine the significance of the difference in the mean species richness and abundance between the forest edge and interior, using only the pitfall trap data, to standardize the analysis. We applied a simple linear regression and $G$ test (Zar 1999) to verify the possible relationship between anuran community parameters (species richness and abundance) and climatic variables (rainfall and temperature). We ran all the statistical tests in the BioEstat 5.3 software (Ayres et al. 2007). The correlations were considered significant when $\mathrm{P} \leq 0.05$. We excluded the exotic species Lithobates catesbeianus (Shaw 1802) from all the analyses.
The anuran nomenclature adopted in the present study was based on Frost (2020), and we verified the conservation status of the species in the International Red List of Endangered Species (IUCN 2020), the Brazilian Red Book of Threatened Animal Species (ICMBIO 2018), and the List of Endangered Anurans of the state of Rio Grande do Sul (Rio Grande do Sul 2014). We classified the reproductive modes of the anuran species as in Haddad et al. (2013), and defined their degree of endemism according to RossaFeres et al. (2017).

\section{Results}

We recorded 26 anuran species in the PEPC, representing 14 genera and seven families (Table 1, Figure 2). The Hylidae was the most diverse family, with nine species ( $\mathrm{n}=9$ species), followed by the Leptodactylidae ( $\mathrm{n}=8 \mathrm{spp}$.), Odontophrynidae ( $\mathrm{n}=3 \mathrm{spp}$.), Bufonidae ( $\mathrm{n}=3 \mathrm{spp}$.), and the Brachycephalidae, Centrolenidae, and Microhylidae, each represented by a single species (Figure 2). We recorded the greatest species richness, 20 species (76.9\% of the total), in the edge of the fragment, while we collected 16 species $(61.5 \%$ of the total) in both the interior of the forest and the open area (Table 1). Three anuran species (11.5\% of the total) were exclusive to both the forest and edge habitat, while two $(7.7 \%)$ were found only in the open area (Figure 3). Eight anuran species (30.7\%) occurred in all three environments, that is, the open area, and the forest edge and interior (Table 1). Five species (19.2\%) were found in both the edge and open area, and four $(15.3 \%)$ were recorded in both types of forest, while only one species $(3.8 \%)$ was found in both the forest interior and the open area (Figure 3). 
Potrich, AP. et al.

Table 1. Anuran species recorded in Parque Estadual do Papagaio Charão, in the municipality of Sarandi, Rio Grande do Sul, Brazil. Sample methods: pitfall trapping (PT) and active search (AS). The reproductive mode (RM) of each species is designated by a number, following the classification of Haddad et al. (2013). The conservation status of each species is defined according to the Brazilian (ICMBio 2018) and international (IUCN 2020) red lists. $\mathrm{LC}=\mathrm{Least}$ Concern, NT $=$ Near Threatened, $\mathrm{VU}=$ Vulnerable, $\mathrm{EN}=$ Endangered, and DD = Deficient Data. ${ }^{1}$ Endemic to the Atlantic Forest and ${ }^{2}$ Endemic to the Mixed Rainforest domain of the southern Atlantic Forest (sensu Rossa-Feres et al. 2017). ${ }^{3}$ Recorded previously.

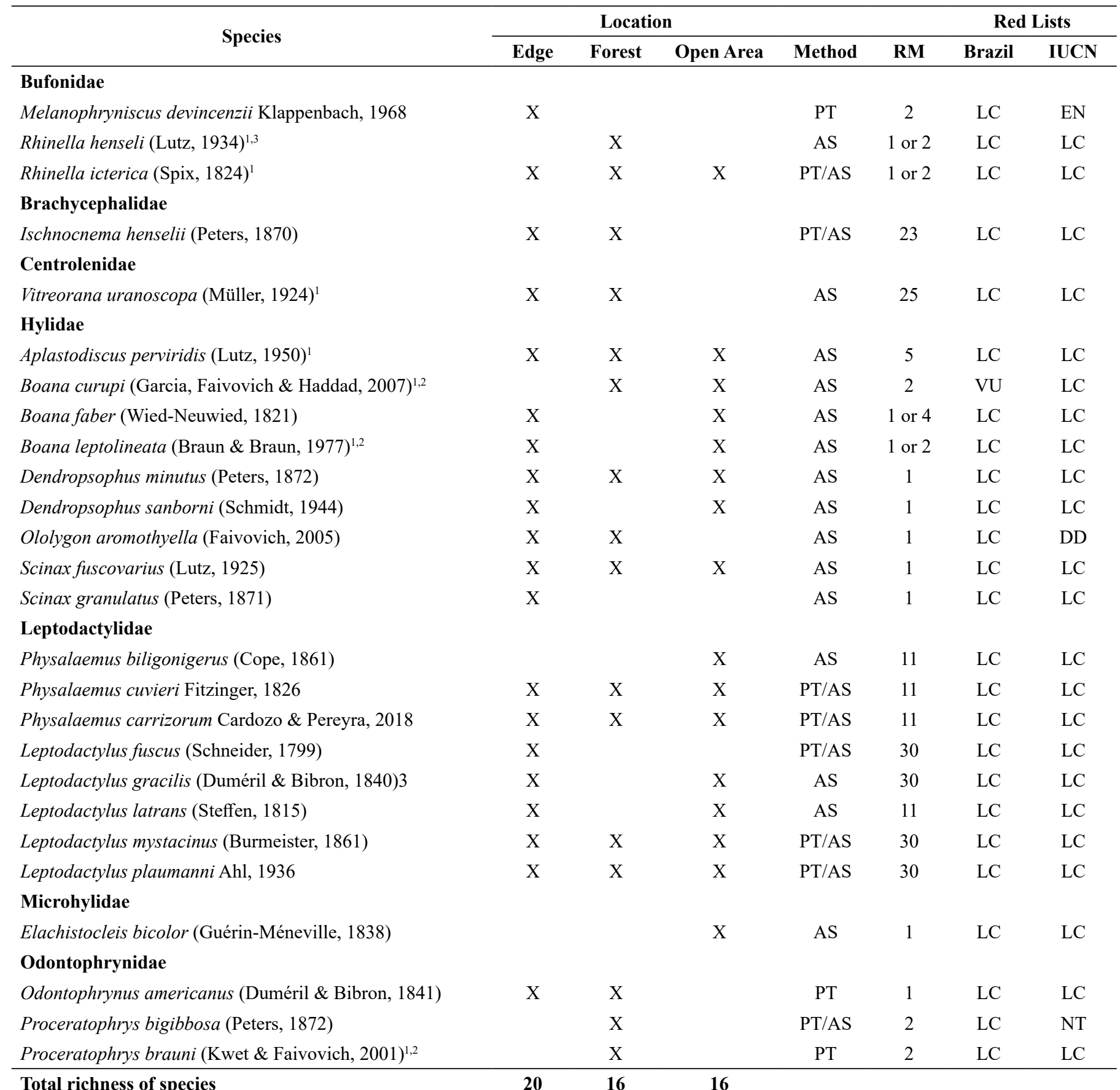

Reproductive modes: (1) exotrophic eggs and tadpoles in standing water; (2) exotrophic eggs and tadpoles in running water; (4) eggs and early larval stages in natural or manmade pools, after flooding, exotrophic tadpoles in streams or puddles; (5) eggs and early larval stages in underground "nests", after flooding, exotrophic tadpoles in streams or puddles; (11) eggs laid in floating foam nests and exotrophic tadpoles in puddles; (23) direct development of eggs on ground; (25) after hatching, the exotrophic tadpoles drop into running water; (30) foam nest with eggs and early larval stages in chambers built underground, after flooding, exotrophic tadpoles in lentic water. Adapted from Haddad et al. (2013). 


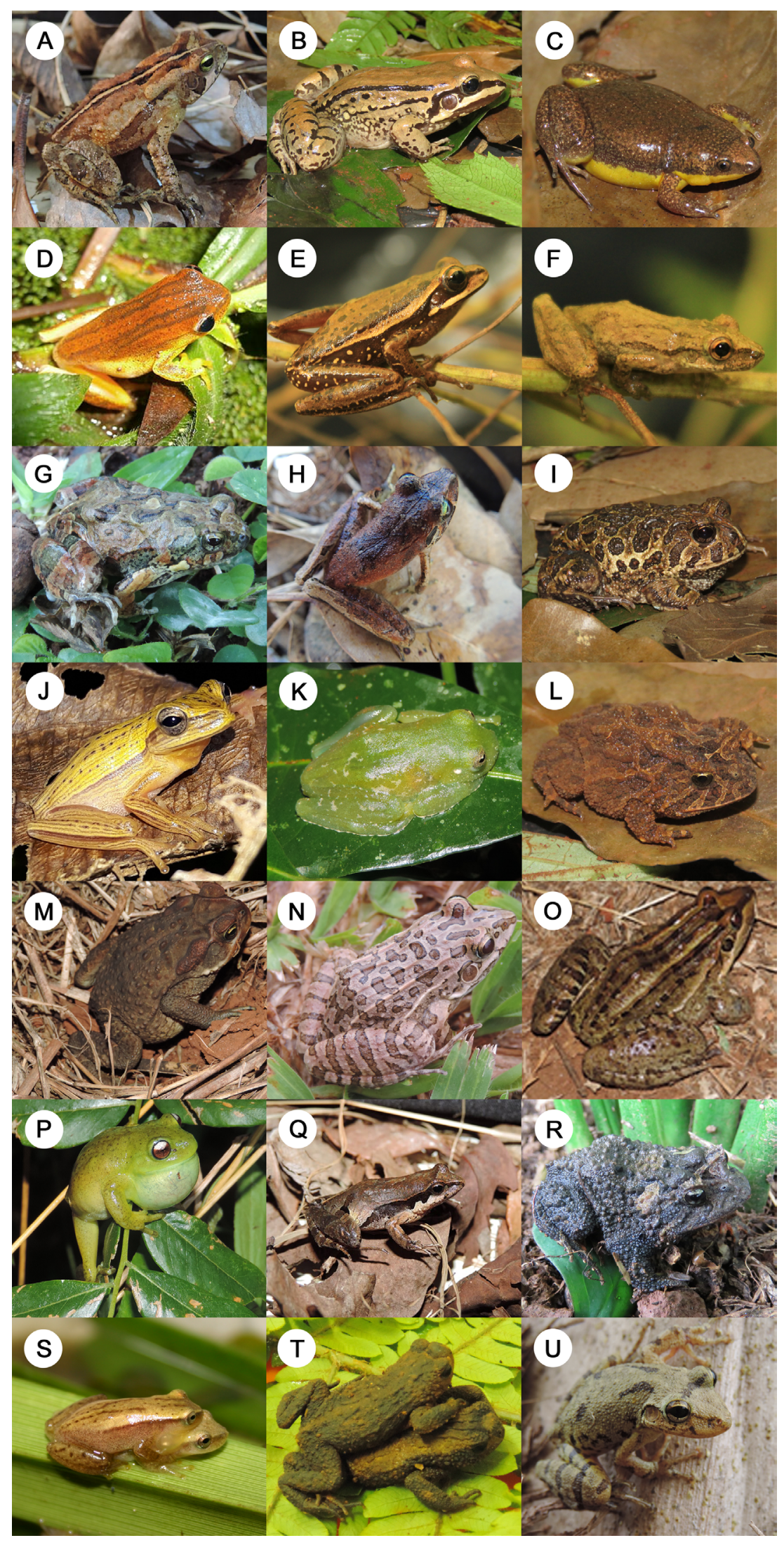

Figure 2. Anurans recorded in the Parque Estadual do Papagaio Charão, in Sarandi, Rio Grande do Sul, Brazil. (A) Rhinella henseli; (B) Leptodactylus mystacinus; (C) Elachistocleis bicolor; (D) Dendropsophus minutus; (E) Boana curupi; (F) Ololygon aromothyella; (G) Physalaemus biligonigerus; (H) Ischnocnema henselii; (I) Odontophrynus americanus; (J) Boana leptolineata; (K) Vitreorana uranoscopa; (L) Proceratophrys brauni; (M) Rhinella icterica; (N) Leptodactylus fuscus; (O) Leptodactylus plaumanni; (P) Aplastodiscus perviridis; (Q) Physalaemus carrizorum; (R) Proceratophrys bigibbosa; (S) Dendropsophus sanborni; (T) Melanophryniscus devincenzii; (U) Scinax granulatus. Photographs: A, D, E, J, K, M, N, O, P, E, R, S, T, and U by N. Zanella; B, C, G, H, and I by L. A. P. Potrich and M. Santos-Pereira. 


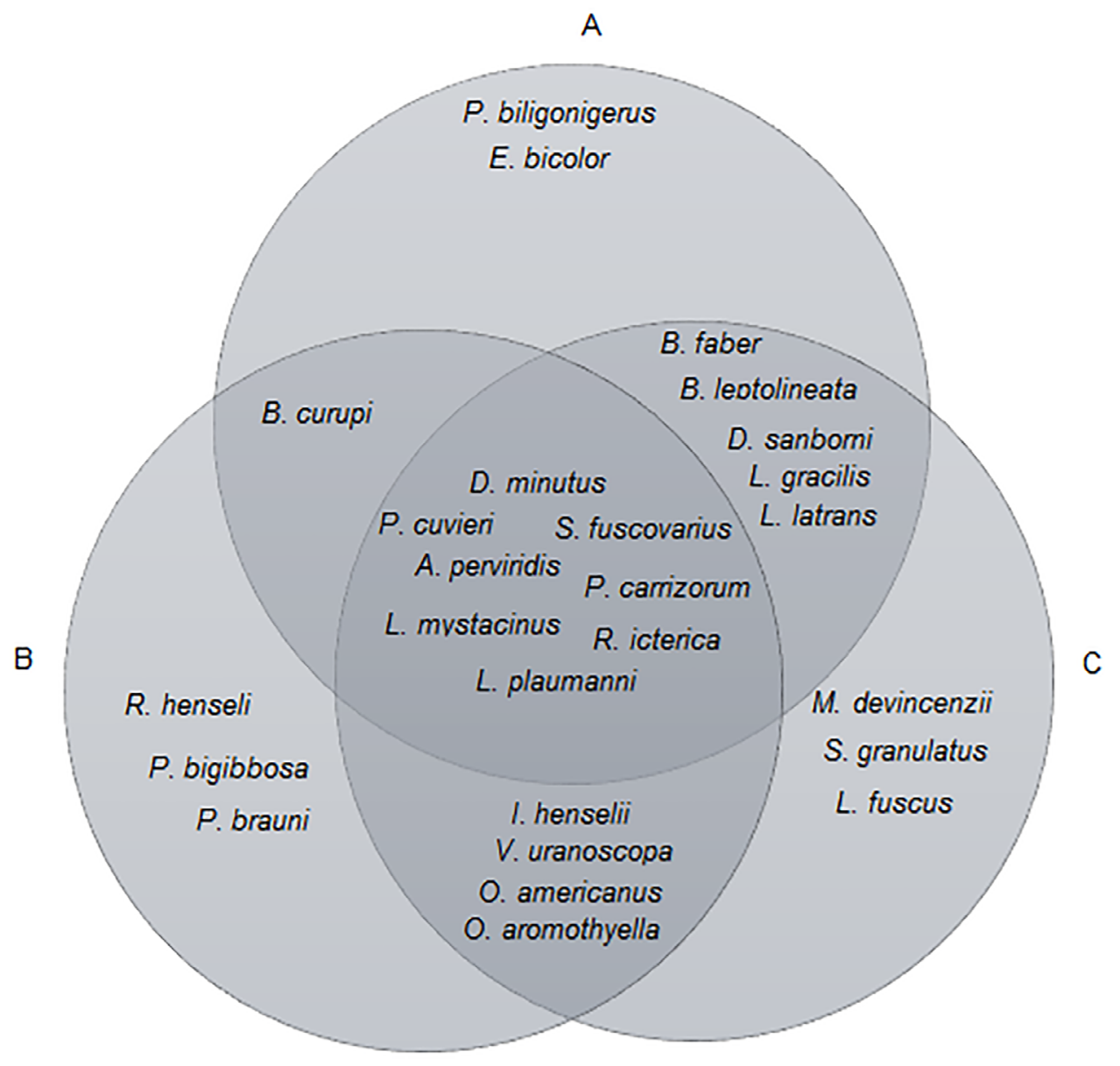

Figure 3. Venn Diagram of the intersection of the composition of anuran species in the three habitat types found in the Parque Estadual do Papagaio Charão, in Sarandi, Rio Grande do Sul, Brazil. A = Open area, B = Forest interior, and C = Forest edge.

A total of 11 anuran species were captured in the pitfall traps, including nine species in the edge and nine in the interior of the forest (Table 1). Melanophryniscus devincenzii and Leptodactylus fuscus were captured exclusively in the edge traps, while Proceratophrys bigibbosa and Proceratophry brauni were captured only in the interior of the forest. The most abundant species captured in the pitfall traps (Figure 4) were Leptodactylus plaumanni $(\mathrm{n}=53)$, Physalaemus cuvieri $(\mathrm{n}=32)$, and Physalaemus carrizorum $(\mathrm{n}=21)$. Neither anuran species richness $(\mathrm{p}=0.2667)$ nor abundance $(\mathrm{p}=0.1320)$ varied significantly between the forest edge and the interior. Physalaemus cuvieri dominated the forest interior, and L. plaumanni was the most abundant species in the edge habitat. By contrast, some species, i.e., Leptodactylus fuscus and $P$. brauni, were recorded only once during the study (Figure 4).

The anuran species richness estimated using the Bootstrap procedure was 25.50 species, with 21.79 species being estimated specifically for the forest edge, 16.63 species for the forest interior, and 15.77 for the open area. The shape of the curve (Figure 5) and the predicted species richness indicate that sampling effort was broadly adequate for all three types of habitat sampled in the PEPC, with only an additional two species being expected from further sampling.
We identified eight anuran reproductive modes in the present study (Table 1). The most frequent mode was mode 1 , found in 11 species (42.3\%), followed by mode 2 , in seven species (26.9\%), mode 11 and 30 , both recorded in four species $(15.3 \%)$, with modes $4,5,23$, and 25 , each being found in a single anuran species $(3.8 \%)$.

Seven $(27 \%)$ of the anuran species recorded in the PEPC are endemic to the Atlantic Forest, with three (11.54\%) being endemic to the Mixed Rainforest formation (Table 1). Melanophryniscus devincenzii is classified as EN (Endangered) and P. bigibbosa as NT (Near Threatened) by the IUCN (2020). Boana curupi is considered EN (Endangered) in the state of Rio Grande do Sul (Rio Grande do Sul 2014) and VU (Vulnerable) in Brazil (ICMBIO 2018), while Vitreorana uranoscopa is classified as Near Threatened in Rio Grande do Sul (Rio Grande do Sul 2014).

Anuran species richness did not vary significantly with temperature $(\mathrm{p}=0.0653)$, although abundance was significantly $(\mathrm{p}<0.0001)$ higher in the warmer months in comparison with the cooler months of the year. Significant correlations were found between rainfall and both anuran species richness $(\mathrm{R}=0.3273, \mathrm{p}<0.0001, \mathrm{n}=42)$ and abundance $(\mathrm{R}=0.3670, \mathrm{p}<0.0001, \mathrm{n}=42)$. 


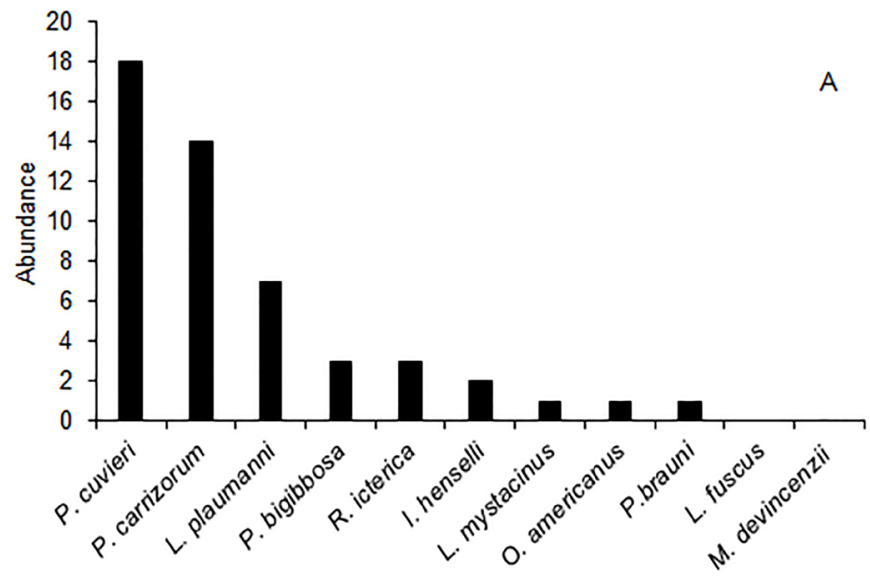

Species



Figure 4. Abundance of anurans captured between March 2018 and February 2019 in the Parque Estadual do Papagaio Charão, in Sarandi, Rio Grande do Sul, Brazil, in two environments: A) the interior of the forest, and B) the edge of the fragment, considering only the pitfall traps data.

\section{Discussion}

The anuran species recorded by us in the PEPC represent $0.36 \%$ of total anuran diversity, worldwide (Frost 2020), and 2.3\% of the Brazilian anuran fauna (Segalla et al. 2019). We also recorded $23.8 \%$ of the species known to occur in the Mixed Rainforest formation of the Atlantic Forest biome (Rossa-Feres et al. 2017). The anuran species richness recorded in the study represented $94.1 \%$ of that estimated, which indicates that the sample area was sampled adequately.

Our findings on the anuran community of the PEPC were similar to those of previous studies conducted at other sites within the Mixed Rainforest formation of the southern Atlantic Forest biome. For example, Zanella et al. (2013) recorded 23 anuran species in the Parque Municipal de Sertão, $60 \mathrm{~km}$ east of the PEPC, including 20 (76.9\%) of the species recorded in the present study. Lucas \& Fortes (2008) inventoried 29 anuran species (28 native and one exotic) in the Floresta National de Chapecó, $120 \mathrm{~km}$ north of the PEPC, including 17


B

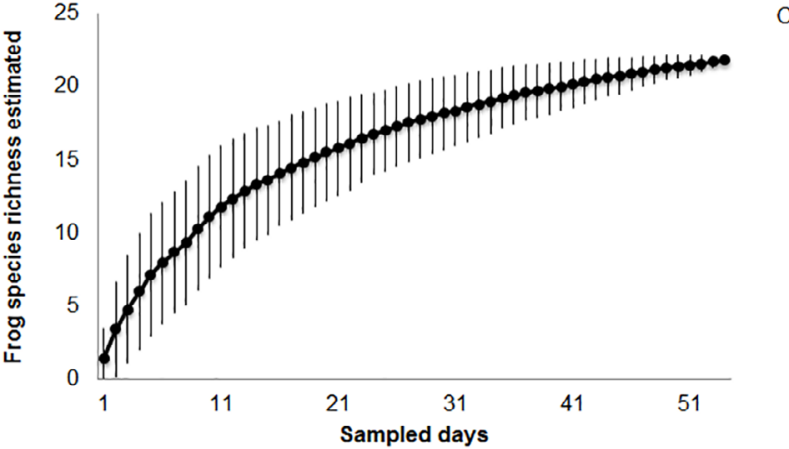

Figure 5. Rarefaction curves (Bootstrap estimator) of the anuran species recorded in the Parque Estadual do Papagaio Charão, in Sarandi, Rio Grande do Sul, Brazil, using active searches and pitfall traps between March 2018 and February 2019. $\mathrm{A}=$ General (all data); $\mathrm{B}=$ Forest interior only; $\mathrm{C}=$ Forest edge only.

$(60.7 \%)$ of the species recorded at this site. Bastiani \& Lucas (2013) recorded 22 native species in the Parque Estadual Fritz Plaumann, in the municipality of Concórdia, in Santa Catarina, southern Brazil, of which, 14 (53.8\%) were recorded in the present study. Slightly further afield, $152 \mathrm{~km}$ northwest of the PEPC, in the semideciduous seasonal forest of the Parque Estadual do Turvo, Iop et al. (2011) recorded 30 anurans, including 21 of the species $(70 \%)$ registered in the present study. This degree of homogeneity in the anuran fauna of the different sites is probably related to the broad phytophysiognomic similarities of the Atlantic Forest domain.

A predominance of hylid species is typical of the Neotropical region (Duellman 1999), in particular in the Atlantic Forest (e.g. Araujo \& Almeida-Santos 2013, Santos-Pereira et al. 2016, Ceron et al. 2017). The family Leptodactylidae is also a prominent component of the anuran fauna of most Atlantic Forest sites (e.g. Conte \& Rossa-Feres 2006, Lucas \& Marocco 2011, Zanella et al. 2013). The leptodactylids are also a prominent group in the Pampa (e.g. Lipinski \& Santos 2014, Bolzan 
et al. 2016), a grassland biome in Rio Grande do Sul, and neighboring areas of Uruguay and Argentina. As the Mixed Rainforest is adjacent to grassland (which is not the Pampa) in the PEPC (Overbeck et al. 2009, SEMA 2020), the composition of its anuran fauna may be influenced by both forest and grassland environments, which may account for the fact that the Hylidae and the Leptodactylidae were the most prominent families in the study area. This ecotonal scenario may also account for the presence in the PEPC of species endemic to the Atlantic Forest biome, i.e., Aplastodiscus perviridis, Vitreorana uranoscopa, Rhinella henseli, and R. icterica, and those with associate distributions within to the Mixed Rainforest phytophysiognomy, that is, Boana curupi, B. leptolineata, and Proceratophrys brauni (Rossa-Feres et al. 2017). Proceratophrys brauni has also been recorded in neighboring areas of Paraguay, Argentina, and Uruguay (Frost 2020).

We recorded a greater species richness in edge areas in comparison with the forest interior and the open area. This forest edge represents the transition between natural habitats which, modified by fragmentation, results in the formation of structurally distinct types of vegetation (Murcia 1995). As the PEPC is located with the transition zone between the Mixed Rainforest and grassland, this edge habitat may be similar to a natural ecotone. The greater species richness found at the forest edge may reflect the ecology of some anurans, which reproduce in open areas, but forage or seek shelter within the forest (Conte \& Rossa-Feres 2007, Lucas \& Fortes 2008, Quesnelle et al. 2015). The intercalation of pastures and forest formations permits different patterns of habitat use, which favor the occurrence of species specialized for the exploitation of both open areas and forested areas (Crivellari et al. 2014). In environments with different phytophysiognomies, such as forest and open areas, species richness is often greatest in areas of ecotone (Maragno et al. 2013). Previous studies have also found greater species richness at the edge of forest fragments (e.g. Urbina-Cardona et al. 2006, Zanella et al. 2013), indicating that anuran communities may be favored by transitional environments. While pitfall traps were not deployed in open area in the present study, the number of species recorded in this habitat was similar to that recorded in the interior of fragment, although it is important to remember that the number of species may be underestimated in open area given that many species may be less detectable using the traditional visual search approach (Cechin \& Martins 2000).

Some anurans, such as Dendropsophus minutus, P. cuvieri, A. perviridis, Leptodactylus mystacinus, L. plaumanni, Scinax fuscovarius, P. carrizorum, and $R$. icterica, occurred in all three of the environments sampled in the present study. This reflects the ecological adaptations of these species, which are generalists with ample geographic ranges (Haddad et al. 2013, Vancine et al. 2018). By contrast, Proceratophrys biggibosa, P. brauni and Rhinella henseli were recorded only in the forest interior. These Proceratophrys species inhabit mountainous areas in subtropical rainforest ranging in altitude from $300 \mathrm{~m}$ to 1200 m a.s.1. (Kwet Di-Bernardo 1999, Kwet \& Faivovich 2001), where they are typically found in rocky streams at the edge or in the interior of dense forests (Santos et al. 2009). Rhinella henseli, in turn, inhabits the forest and, during the breeding season, it is found in small streams, temporary pools (Kwet et al. 2010, Haddad et al. 2013, Lucas et al. 2018). Species found in both the forest and the edge (Table 1) are typically less demanding of habitat, allowing them to exploit different environments.
Leptodactylus plaumanni was recorded in all three environments, but was captured more frequently in the pitfall traps deployed in the edge of the forest. This common species is found in both forest and grassland (Kwet et al. 2010), and in Brazil, it is limited to the southern extreme of the country (de Sá et al. 2014, Frost 2020). Physalaemus cuvieri was the most abundant species in the interior of the forest fragment at PEPC, as recorded by Maragno et al. (2013). This species is widely distributed in South America (Frost 2020), and is typical of open areas (Kwet et al. 2010). The location of the PEPC within the Mixed Rainforest domain, which was originally formed by a mosaic of forest and grassland, may account for its presence in the forest at this site. The ecological characteristics of a species may often depend on its ability to adapt to a given environment (UrbinaCardona et al. 2006).

A majority of the anurans recorded in the PEPC present reproductive mode $1(42.3 \%)$, in which the eggs are deposited in water, where the exotrophic tadpoles develop, or mode $2(26.9 \%)$, where the eggs are deposited in lotic water, where the tadpoles develop. Laying eggs directly on the surface of the water (mode 1) is the most primitive and generalized anuran reproductive mode (Duellman \& Trueb 1994), and a large number of studies have shown that this mode is the most common in most anuran communities (e.g. Leivas et al. 2015, Nazaretti \& Conte 2015, Santos-Pereira et al. 2016). The diversity of reproductive modes in an anuran community tends to reflect the heterogeneity of the environment, rather than phylogenetic relationships (Duellman \& Trueb 1986). The occurrence of eight reproductive modes in the PEPC is typical of Atlantic Forest anurans, given the high humidity and ample diversity of microhabitats found in this forest (Haddad \& Prado 2005). Areas with prolonged rains, such as the PEPC, tend to provide conditions for a broad range of reproductive modes, in contrast with more arid areas, with seasonal climates, that tend to restrict reproduction to more specialized modes that are more resistant to desiccation (Silva et al. 2012).

Vitreorana uranoscopa is a small arboreal anuran, which is listed as Vulnerable in Rio Grande do Sul (Rio Grande do Sul 2014). Recent studies have shown that the distribution of this species is expanding (Machado et al. 2010, 2014), with it being recorded increasingly in small fragments of forest (Savaris et al. 2011). At PEPC, the species was encountered only in the forest, including the edge. The occurrence of $V$. uranoscopa at the edge of the forest in the PEPC may be related to its ecological characteristics, given that it is found in the streams that run from the interior of the forest fragment to its edges, resulting in the dispersal of this anuran throughout the area. For many amphibian species, in fact, the presence of specific reproductive habitats may be the primary determinant of the occurrence of a species at a given site, irrespective of the other habitats available in the area (Zimmerman \& Bierregaard 1986). Boana curupi, which is also endangered, is typically found in forested vegetation at the margins of shallow streams (Garcia et al. 2007, Iop et al. 2009, Lucas \& Garcia 2011, Fontana et al. 2017), and in the present study, it was found vocalizing in a marsh, in an open area near the study forest.

In the present study, precipitation had a significant influence on anuran species richness and abundance in the PEPC, whereas temperature influenced only abundance, as observed in previous studies (Both et al. 2008, Conte \& Rossa-Feres 2007, Santos \& Conte 2014, 
Goyannes-Araújo et al. 2015). Amphibian reproduction is influenced primarily by climatic factors (Duellman \& Trueb 1986), and in Brazil, a number of studies have shown that precipitation is the principal factor determining anuran species richness, in addition to the diversity of reproductive modes (Vasconcelos et al. 2010, Maffei et al. 2011).

Lithobates catesbeianus, an exotic and invasive species, was recorded in all three environments surveyed in the PEPC. This species is considered to be one of the principal threats to native anurans, given its capacity to adapt to different environments and compete with native anurans (Rocha et al. 2011, Almeida et al. 2020), which often in the decline of resident populations (Both et al. 2011, Silva et al. 2011, Santos-Pereira \& Rocha 2015). The presence of L. catesbianus in a protected area the size of the PEPC reflects its capacity to invade novel environments, which is a potential cause for concern over the long term.

The anuran species recorded here in the Parque Estadual do Papagaio Charão appear to be a reliable estimate of the diversity of anurans found in this protected area in Rio Grande do Sul. Our findings indicate that the anuran diversity of the area may be the result of the interface of the forest ecosystems and grassland environments found in the park. The presence of threatened species in the PEPC reinforces the importance of this protected area for the conservation of the anuran communities of the Atlantic Forest biome. This is especially important in the context of the study region, where the Mixed Rainforest has suffered extensive impact and loss of cover over the past few years.

\section{Supplementary Material}

The following online material is available for this article: Appendix.

\section{Acknowledgements}

We are grateful to the University of Passo Fundo Institution for granting a scholarship through the Graduate Program in Environmental Sciences. We also thank the Papagaio Charão State Park for logistic support during fieldwork, and SEMA (State Environment and Infrastructure Secretariat) for authorizing the research. We are also grateful to the Herpetology ICB/UPF lab team, Élinton Rezende and Roberto Tomasi Junior for their support during fieldwork.

\section{Author Contributions}

Ana Paula Potrich: Contributed to the collection, analysis, and interpretation of the data, and wrote the manuscript.

João Paulo Soares, Carlos Toffolo and Thaís Ascoli-Morrete: Contributed to data collection.

Manuela Santos-Pereira and Noeli Zanella: Contributed to the preparation of the manuscript, reviewed it critically, and added intellectual content.

\section{Conflicts of Interest}

The authors declare that they have no conflicts of interest with regard to the publication of this manuscript.

\section{References}

ALMEIDA-GOMES, M. \& ROCHA, C.F.D. 2014. Landscape connectivity may explain anuran species distribution in an Atlantic forest fragmented area. Landsc. Ecol. 29(1):29-40.

ALMEIDA, P.C. DE, HARTMANN, M.T. \& HARTMANN, P.A. 2020. How riparian forest integrity influences anuran species composition: a case study in the Southern Brazil Atlantic Forest. Animal Biodiversity and Conservation. 43(2):209ri19.

ANDRADE, E.B., WEBER, L.N. \& LEITE, J.R.S.A. 2017. Anurans of the Parque Estadual do Mirador, a remnant of Cerrado in the state of Maranhão, Northeastern Brazil. Biota Neotrop. 17(4): e20160260. http://dx.doi. org/10.1590/1676-0611-BN-2016-0260 (last access on 10/06/2020).

ARAUJO, C.D.O. \& ALMEIDA-SANTOS, S.M.D. 2013. Composição, riqueza e abundância de anuros em um remanescente de Cerrado e Mata Atlântica no estado de São Paulo. Biota Neotrop. 13(1): 265-275 https://doi.org/10.1590/ S1676-06032013000100026 (last access on 26/07/2019).

AYRES, M., AYRES, J.M., AYRES, D.L. \& SANTOS, A.A.S. 2007. BioEstat: Aplicações Estatísticas nas áreas das ciências biológicas e médicas. Sociedade Civil Mamirauá/MCT-CNPq, Belém.

BASTIANI, V.I.M.D. \& LUCAS, E.M. 2013. Anuran diversity (Amphibia, Anura) in a Seasonal Forest fragment in southem Brazil. Biota Neotrop. 13(1): 255-264 https://doi.org/10.1590/S1676-06032013000100025 (last access on 25/07/2019).

BECKER, C.G., FONSECA, C.R., HADDAD, C.F.B., BATISTA, R.F. \& PRADO, P.I. 2007. Habitat split and the global decline of amphibians. Science 318(5857):1775-1777.

BLAUSTEIN, A.R. \& KIESECKER, J.M. 2002. Complexity in conservation: Lessons from the global decline of amphibian populations. Ecol. Lett. 4:597-608.

BOLZAN, A.M.R.; SACCOL, S.A. \& SANTOS, T.G.D. 2016. Composition and diversity of anurans in the largest conservation unit in Pampa biome, Brazil. Biota Neotrop. 16(2): 1-14 https://doi.org/10.1590/1676-0611BN-2015-0113 (last access on 26/07/2019).

BOTH, C., KAEFER, Í.L., SANTOS, T.G. \& CECHIN, S.T.Z. 2008. An austral anuran assemblage in the Neotropics: seasonal occurrence correlated with photoperiod. J. Nat. Hist. 42(3-4): 205-222.

BOTH, C., LINGNAU, R., SANTOS-JR, A., MADALOZZO, B., LIMA, L.P. \& GRANT, T. 2011. Widespread Occurrence of the American Bullfrog, Lithobates catesbeianus (Shaw, 1802) (Anura: Ranidae), in Brazil. S. Am. J. Herpetol. 6(2):27-134.

CERON, K., LUCAS, E.M. \& ZOCCHE, J.J. 2017. Anurans of Parque Estadual da Serra Furada, Santa Catarina, Southern Brazil. Herpetol. Notes 10:287-296.

CECHIN S.Z., MARTINS M. 2000. Eficiência de armadilhas de queda (pitfall traps) em amostragens de anfíbios e répteis no Brasil. Rev. Bras. Zool. 17(3):729-740.

COLWELL, R.K. 2013. Estimates: statistical estimation of species richness and shared species from samples. Version 9.1.0. User's Guide and application. http://viceroy.eeb.uconn.edu/estimates/EstimateSPages/ EstimateSRegistration.htm. (last access on 29/07/2019).

CONTE, C.E. \& ROSSA-FERES, D. DE C. 2006. Diversidade e ocorrência temporal da anurofauna (Amphibia, Anura) em são José dos Pinhais, Paraná, Brasil. Rev. Bras. Zool. 23(1):162-175.

CONTE, C.E. \& ROSSA-FERES, D. DE C. 2007. Riqueza e distribuição espaço-temporal de anuros em um remanescente de Floresta de Araucária no sudeste do Paraná. Rev. Bras. Zool. 24(4):1025-1037.

CORN, P.S. 1994. Straight-line drift fences and pitfall traps. Smithsonian Institution Press, Washington, p109-117.

COSTA, T.R.N., CARNAVAL, A.C.O.Q. \& TOLEDO, L.F. 2012. Mudanças climáticas e seus impactos sobre os anfíbios brasileiros. Rev. Biol. 8: 33-37.

CRIVELLARI, L.B., LEIVAS, P.T., LEITE, J.C.M., DA SILVA GONÇALVES, D., MELlO, C.M., DE CERQUEIRA ROSSA-FERES, D., \& CONTE, C.E. 2014. Amphibians of grasslands in the state of Paraná, southern Brazil (Campos Sulinos). Herpetol. Notes 7:639-654. 
CRUMP, M.L. \& SCOTT-JR., N. 1994. Visual encounter surveys. In Measuring and Monitoring Biological Diversity -Standard Methods for Amphibians (HEYER, W.E., DONELLY, M.A., MCDIARMID, R.W., HAYEK, L.A.C. \& FOSTER, M.S, eds). Smithsonian Institution Press, Washington, p. 84-92.

DE SÁ, R.O., GRANT, T., CAMARGO, A., HEYER, W.R., PONSSA, M.L., \& STANLEY, E. 2014. Systematics of the neotropical genus Leptodactylus Fitzinger, 1826 (Anura: Leptodactylidae): phylogeny, the relevance of non-molecular evidence, and species accounts. S. Am. J. Herpetol. 9(s1).

DUELLMAN, W.E. \& TRUEB, L. 1986. Biology of amphibians. McGrawHill, New York.

DUELLMAN, W.E. \& TRUEB, L. 1994. Biology of Amphibians. McGraw-Hill Publications Corporation, New York.

DUELLMAN, W.E. 1999. Distribution patterns of amphibians in South America. The Johns Hopkins University Press, Baltimore.

FERRANTE, L., BACCARO, F.B., FERREIRA, E.B., SAMPAIO, M.F. DE O., SANTOS, T., JUSTINO, R.C., \& ANGULO, A. 2017. The matrix effect: how agricultural matrices shape forest fragment structure and amphibian composition. J. Biogeogr. 44(8):1911-1922.

FIORILLO, B.F.; FARIA, C.S.; SILVA, B.R. \& MARTINS, M. 2018. Anurans from preserved and disturbed areas of Atlantic Forest in the region of Etá Farm, municipality of Sete Barras, state of São Paulo, Brazil. Biota Neotrop. 18(4): 1-15 https://doi.org/10.1590/1676-0611-bn-2017-0509 (last access on $25 / 07 / 2019$ ).

FOERSTER, N.E. \& CONTE, C.E. 2018. Anuran diversity in an Araucaria Forest fragment and associated grassland area in a sub-tropical region in Brazil. Herpetol. Notes 11:421-428.

FONTANA, R.B., SANGALLI, L. \& ZANELLA, N. 2017. Distribution extension of Hypsiboas curupi Garcia, Faivovich \& Haddad, 2007 (Amphibia: Anura: Hylidae) for Rio Grande do Sul, southern Brazil. Check List 13(1):1-3.

FROST, D.R. 2020. Amphibian Species of the World: an Online Reference. Version 6.0. American Museum of Natural History, New York, USA http://research. amnh.org/herpetology/amphibia/index.html. (last access on 20/06/2020).

GARCIA, P.C.A., FAIVOVICH, J. \& HADDAD, C.F.B. 2007. Redescription of Hypsiboas semiguttatus, with the Description of a New Species of the Hypsiboas pulchellus Group. Copeia 4:933-951.

GOYANNES-ARAÚJO, P., SIQUEIRA, C.C., LAIA, R.C., ALMEIDASANTOS, M., GUEDES, D.M. \& ROCHA, C.F. D. 2015. Anuran species distribution along an elevational gradient and seasonal comparisons of leaf litter frogs in an Atlantic. Herpetol. J 25:75-81.

HADDAD, C.F.B. \& PRADO, C.P.A. 2005. Reproductive Modes in Frogs and Their Unexpected Diversity in the Atlantic Forest of Brazil. BioScience 55(3):207.

HADDAD, C.F.B., TOLEDO, L.F., PRADO, C.P.A., LOEBMANN, D., GASPARINI, J.L. \& SAZIMA, I. 2013. Guia dos Anfíbios da Mata Atlântica: Diversidade e Biologia. Anolisbooks, São Paulo.

HADDAD, N.M., BRUDVIG, L.A., CLOBERT, J., DAVIES, K.F., GONZALEZ, A., HOLT. R., LOVEJOY, T.E., SEXTON, J.O., AUGUSTIN, M.P., COLLINS, C.D., COOK, W.M., DAMSCHEN, E.I, WERS, R.M., FOSTER, B.L., JENKINS, C., KING, A.J., LAURANCE, W.F, LEVEY, D.J., MARGULES, C.R., MELBOURNE, B.A., NICHOLLS, A.O., ORROCK, J.L., SONG, D.X. \& TOWSCHEND, J.R. 2015. Habitat fragmentation and its lasting impact on Earth's ecosystems. Sci. Adv. 1(2):1-9.

INSTITUTO CHICO MENDES DE CONSERVAÇÃO DA BIODIVERSIDADE. 2018. Livro Vermelho da Fauna Brasileira Ameaçada de Extinção: Volume V - Anfíbios. 1 ed. Brasília, Distrito Federal.

IOP, S., CALDART, V.M., ROCHA, M.C.D., PAIM, P.M. \& CECHIN, S.Z. 2009. Amphibia, Anura, Hylidae, Hypsiboas curupi Garcia, Faivovich and Haddad, 2007: first record for the state of Rio Grande do Sul, Brazil. Check List 5(4):860-862.

IOP, S., CALDART, V.M., SANTOS, T.G.D. \& CECHIN, S.Z. 2011. Anurans of turvo state park: testing the validity of seasonal forest as a new biome in Brazil. J. Nat. Hist. 45(39-40): 244-2461.

IUCN (INTERNATIONAL UNION FOR CONSERVATION OF NATURR.) 2020. IUCN Red List of Threatened Species. Version 2020.1. http://www. iucnredlist.org. (last access on 20/06/2020).
KWET, A. \& DI-BERNARDO, M. 1999. Pró-Mata: Anfíbios. Porto Alegre, Brasil.

KWET, A. \& FAIVOVICH, J. 2001. Proceratophrys bigibbosa species group (Anura: Leptodactylidae), with description of a new species. 1 ed. Copeia 1:203-2015.

KWET, A., LINGNAU R. \& DI-BERNARDO, M. 2010. Pró-Mata: Anfíbios da Serra Gaúcha, Sul do Brasil. 2 ed. Porto Alegre, Brasil.

LAURENCE, W.F. 2008. Theory meets reality: How habitat fragmentation research has transcended island biogeographic theory. Biol. Conserv. 7:1731-1744.

LEIVAS, P.T., BELTRAMIN, A.S., MACHADO, R.A. \& MOURA, M.O. 2015. Anuran richness (Amphibia: Anura) in remnant forest fragments of Araucaria Forest and Atlantic Rainforest in Paraná, Brazil. Herpetol. Notes 8:661-667.

LEIVAS, P.T. \& HIERT, C. 2016. Anuran richness in remnants of Araucaria forest, Paraná, Brazil. Herpetol. Notes 9:15-21.

LIPINSKI, V.M., \& SANTOS, T.G. 2014. Estrutura e organização espacial de duas comunidades de anuros do bioma Pampa. Iheringia, Sér. Zool. 104(4):462-469.

LUCAS, E.M. \& FORTES, V.B. 2008. Frog diversity in the Floresta Nacional de Chapecó, Atlantic Forest of southern Brazil. Biota Neotrop. 8(3): 51-61 https:// doi.org/10.1590/s1676-06032008000300004 (last access on 27/07/2019).

LUCAS, E.M. \& MAROCCO, J.C. 2011. Anurofauna (Amphibia, Anura) em um remanescente de Floresta Ombrófila Mista no Estado de Santa Catarina, Sul do Brasil. Biota Neotrop. 11(1): 377-384 https://doi.org/10.1590/s167606032011000100035 (last access on 23/07/2019).

LUCAS, E.M. \& GARCIA, P.C.A. 2011. Amphibia, Anura, Hylidae Rafinesque, 1815 and Hylodidae Günther, 1858: Distribution extension and new records for Santa Catarina, southern Brazil. Check List 7(1):13-16.

LUCAS, E.M., BASTIANI, V.I.M.D. \& LINGNAU, R. 2018. Geographic distribution, habitat use and vocalizations of the leaf-litter frog Ischnocnema henselii (Anura: Brachycephalidae) in the subtropical Atlantic Forest. Rev. Bras. Zoo. 19(1):151-162.

MACHADO, I.F., BÜHLER, D., ABADIE, M., SANTOS, A.P.J. \& SANTOS, R.R. 2014. Distribution extension of Vitreorana uranoscopa (Anura: Centrolenidae) in the state of Rio Grande do Sul, southern Brazil. Herpetol. Notes 7:443-446.

MACHADO, I.F., MOREIRA, L.F.B., SILVA, R.B.D., BECKER, R.G. \& MESQUITA, A.S.O. 2010. Amphibia, Anura, Centrolenidae, Vitreorana uranoscopa (Müller, 1924): Distribution extension in the state of Rio Grande do Sul, Brazil. Check List 6(3):410-411.

MAFFEI, F.; UBAID, F.K. \& JIM, J. 2011. Anurofauna em área de cerrado aberto no município de Borebi, estado de São Paulo, Sudeste do Brasil: uso do habitat, abundância e variação sazonal. Biota Neotrop. 11(2): 221-233. https://doi. org/10.1590/s1676-06032011000200023 (last access on 29/07/2019).

MARAGNO, F.P., SANTOS, T.G. \& CECHIN, S.Z. 2013. The role of phytophysiognomies and seasonality on the structure of ground-dwelling anuran (Amphibia) in the Pampa biome, Southern Brazil. An. Acad. Bras. Ciênc. 85(3):1105-1115.

MARTINS, A., PONTES, R., MATTEDI, C., FRATANI, J., MURTA-FONSECA, R., RAMOS, L., \& BRANDÃO, A. 2014. Anuran community of a coastal Atlantic Forest fragment in the state of Rio de Janeiro, southeastern Brazil. Salamandra 50(1):27-39.

MURCIA, C. 1995. Edge effects in fragmented forests: implications for conservation. Trends Ecol. Evol. 10(2):58-62.

NAZARETTI, E.M. \& CONTE, C.E. 2015. Anurofauna de um remanescente alterado de floresta estacional semidecidual as margens do Rio Paranapanema. Iheringia, Sér. Zool. 105(4):420-429.

OLIVEIRA-FILHO, A.T., BUDKE, J.C., JARENKOW, J.A., EISENLOHR, P.V. \& NEVES, D.R.M., 2013. Delving into the variations in tree species composition and richness across South American subtropical Atlantic and Pampean forests. J. Plant Ecol. 8(3):242-260.

OVERBECK, G.E., MÜLLER, S.C., FIDELIS, A., PFADENHAUER, J., PILLAR, V.P., BLANCO, C., BOLDRINI, I., BOTH, R. \& FORNECK E. 2009. Os Campos Sulinos: um bioma negligenciado. In Campos Sulinos: conservação e uso sustentável da biodiversidade (V.P. Pillar, S.C. Müller, Z.M.S. Castilhos \& A.V.A. Jacques, eds). Brasília: MMA, p. 26-41. 
PFEIFER, M., LEFEBVRE, V., PERES, C.A., BANKS-LEITE, C., WEARN, O.R., MARSH, C.J., BUTCHART, S.H.M, ARROYO-RODRÍGUES, V., BARLOW, J., CEREZO, A., CISNEROS, L., D'CRUZE, N., FARIA, D., HADLEY, A., HARRIS, S.M., KLINGBEIL, B.T., KORMANN, U., LENS, L., MEDINA-RANGEL, G.F., MORANTE-FILHO, J.C., OLIVIER, P., PETERS, S.L., PIDGEON, A., RIBEIRO, D.B., SCHERBER, C., SCHENEIDER-MAUNOURY, L., STRUEBIG, M., URBINA-CARDONA, N., WATLING, J.I., WILLING, M.R., WOOD, E.M. \& EWERS, R. M. 2017. Creation of forest edges has a global impact on forest vertebrates. Nature 551:187-191.

QUESNELLE, P.E., LINDSAY, K.E. \& FAHRIG, L. 2015. Relative effects of landscape-scale wetland amount and landscape matrix quality on wetland vertebrates: A meta-analysis. Ecol. Appl. 25(3):812-825.

RIBEIRO, J.W., SIQUEIRA, T., BREJÃO, G.L. \& ZIPKIN, E.F. 2018. Effects of agriculture and topography on tropical amphibian species and communities. Ecol. Appl. 28(6):1554-1564.

RIBEIRO, M.C., METZGER, J.P., MARTENSEN, A.C., PONZONI, F.J. \& HIROTA, M.M. 2009. The Brazilian Atlantic Forest: How much is left, and how is the remaining forest distributed? Implications for conservation. Biol. Conserv. 142(6):1141-1153.

RIO GRANDE DO SUL. 2014. Decreto n 51.797, de 08 de setembro de 2014 Declara as Espécies da Fauna Silvestre Ameaçadas de Extinção no Estado do Rio Grande do Sul. Governo do Estado do Rio Grande do Sul, Palácio Piratini, Porto Alegre.

ROCHA, C.F.D., BERGALLO, H.G., ALVES, M.A.S. \& SLUYS, M.V. 2003. A biodiversidade nos grandes remanescentes florestais do Estado do Rio de Janeiro e nas restingas da Mata Atlântica. Editora Rima, São Carlos.

ROCHA, C.F.D., BERGALLO, H.G. \& MAZZONI, R. 2011. Biological Invasions: Economic and Environmental Costs of allien plant, animal and microbe species. 2ed. Taylor \& Francis Group. CRC Press, New York.

ROSSA-FERES, D.C., GAREY, M.V., CARAMASCHI, U., NAPOLI, M.F., NOMURA, F., BISPO, A.A., BRASILEIRO, C.A., THOMÉ, M.T.C., SAWAYA, R.J., CONTE, C.E., CRUZ, C.A.G., NACIMENTO, L.B., GASPARINI, J.L., ALMEIDA, A.D.P., \& HADDAD, C.F.B. 2017. Anfíbios da Mata Atlântica: Lista de espécies, histórico dos estudos, biologia e conservação. In Revisões em Zoologia: Mata Atlântica (MONTEIROFILHO, E.L.D.A. \& CONTE, C.E, eds.). Editora UFPR, Brazil, p. 237-314.

SANTOS, E.J. \& CONTE, C.E. 2014. Riqueza e distribuição temporal de anuros (Amphibia: Anura) em um fragmento de Floresta Ombrófila Mista. Iheringia, Sér. Zool. 104(3):323-333.

SANTOS, R.R., COLOMBO, P., LEONARDI, S.B., ZANK, C., SCHOSSLER, M., VIEIRA, K., GRANT, TARAN, BORGES-MARTINS, M. \& VERRASTRO, L. 2009. Amphibia, Anura, Cycloramphidae, Proceratophrys bigibbosa (Peters, 1872) and Proceratophrys brauni Kwet and Faivovich, 2001: distribution extension and new state record. Check List 5(4):922-925.

SANTOS-PEREIRA, M. \& ROCHA, C.F.D. 2015. Invasive bullfrog Lithobates catesbeianus (Anura: Ranidae) in the Paraná state, Southern Brazil: a summary of the species spread. Rev. Bras. Zoo. 16:141-147.

SANTOS-PEREIRA, M., MILANI, D., BARATA-BITTENCOURT, L.F., IAPP, T.M. \& ROCHA, C.F. D. 2016. Anuran species of the Salto Morato Nature Reserve in Paraná, southern Brazil: review of the species list. Check List 12(3):1-11.

SAUNDERS, D.A., HOBBS, R.J. \& MARGULES, C.R. 1991. Biological consequences of ecosystem fragmentation: a review. Conserv. Biol. 5:18-32.

SAVARIS, M., LAMPERT, S., LUCAS, E.M., PARES, A.V.D.R., ORSATO, J., REZENDE, É.L. \& ARGERICH, G.R. 2011. Amphibia, Anura, Centrolenidae, Vitreorana uranoscopa (Müller, 1924): New record for the northeastern region of the state of Rio Grande do Sul, Brazil. Check List 7(6): 841-842.

SCHNEIDER-MAUNOURY, L., LEFEBVRE, V., EWERS, R.M., MEDINARANGEL, G.F., PERES, C.A., SOMARRIBA, E., URBINA-CARDONA, N. \& PFEIFER, M. 2016. Abundance signals of amphibians and reptiles indicate strong edge effects in Neotropical fragmented forest landscapes. Biol. Conserv. 200:207-215.

SECRETARIA DO MEIO AMBIENTE E INFRAESTRUTURA - SEMA. 2020 Parque Estadual do Papagaio Charão. http://www.sema.rs.gov.br/parqueestadual-do-papagaio-charao (last access on 20/06/2020).
SEGALLA, M.V, CARAMASCHI, U., CRUZ, C.A.G., GARCIA, P.C.A., GRANT, T., HADDAD, C.F.B., SANTANA, D.J., TOLEDO, L.F. \& LANGONE, J.A. 2019. Brazilian Amphibians: List of Species. Herpetol. Bras. 8(1):65-96.

SILVA, E.T.D., RIBEIRO, O.P.F. \& FEIO, R.N. 2011. Predation of Native Anurans by Invasive Bullfrogs in Southeastern Brazil: Spatial Variation and Effect of Microhabitat use by Prey. S. Am. J. Herpetol. 6(1):1-10.

SILVA, F.R.D., ALMEIDA-NETO, M., PRADO, V.H.M.D., HADDAD, C.F.B. \& ROSSA-FERES, D.D.C. 2012. Humidity levels drive reproductive modes and phylogenetic diversity of amphibians in the Brazilian Atlantic Forest. J. Biogeogr. 39(9):1720-1732

SILVA, E.T.D., PEIXOTO, M.A.A., LEITE, F.S.F., FEIO, R.N. \& GARCIA, P.C.A. 2018. Anuran Distribution in a Highly Diverse Region of the Atlantic Forest: The Mantiqueira Mountain Range in Southeastern Brazil. Herpetologica 74(4):294-305.

SILVA, F.R.D., CANDEIRA, C.P. \& ROSSA-FERES, D.D.C. 2012. Dependence of anuran diversity on environmental descriptors in farmland ponds. Biodivers. Conserv. 21(6):1411-1424.

TITON, B. \& GOMES, F.R. 2015. Relation between water balance and climatic variables associated with the geographical distribution of anurans. Plos one 10(10):1-19.

TOLEDO, L.F. \& R.F. BATISTA. 2012. Integrative study of Brazilian anurans: Geographic distribution, size, environment, taxonomy, and conservation. Biotropica 44(6):785-792.

URBINA-CARDONA, J.N., OLIVARES-PÉREZ, M., \& REYNOSO, V.H. 2006. Herpetofauna diversity and microenvironment correlates across a pastureedge-interior ecotone in tropical rainforest fragments in the Los Tuxtlas Biosphere Reserve of Veracruz, Mexico. Biol. Conserv. 132(1):61-75.

VANCINE, M.H., DUARTE, K.D.S., SOUZA, Y.S. D., GIOVANELLI, J.G.R., MARTINS-SOBRINHO, P.M., LÓPEZ, A., BOVO, R.P., MAFFEI, F., LION, B.M., RIBEIRO, J.W.J., BRASSALOTI, R., COSTA, C.O.R.D., SAWAKUCHI, H.O., FORTI, L.R, CACCIALI, P., BERTOLUCI, J., HADDAD, C.F.B. \& RIBEIRO, M.C. 2018. ATLANTIC AMPHIBIANS a data set of amphibian communities from the Atlantic Forests of South America. Ecology 99(7):1692.

VASCONCELOS, T.D.S., SANTOS, T.G.DOS, HADDAD, C.F.B. \& ROSSAFERES, D.D.C. 2010. Climatic variables and altitude as predictors of anuran species richness and number of reproductive modes in Brazil. J. Trop. Ecol. 26(4): 423-432.

VASCONCELOS, T.S., PRADO, V.H.M., SILVA, F.R.D. \& HADDAD, C.F.B. 2014. Biogeographic distribution patterns and their correlates in the diverse frog fauna of the atlantic forest hotspot. Plos one 9(8):1-9.

VASCONCELOS, T.S. \& NASCIMENTO, B.T.M.D. 2016. Potential ClimateDriven Impacts on the Distribution of Generalist Treefrogs in South America. Herpetologica 72(1):1-9.

WHITTAKER, K., KOO, M.S., WAKE, D.B., \& VREDENBURG, V.T. 2013. Global Declines of Amphibians. Encyclopedia of Biodiversity. 2(3): 691-699.

ZANELLA, N.; PAULA, A., D.; GUARAGNI, S.A. \& MACHADO, L.D.S. 2013. Herpetofauna do Parque Natural Municipal de Sertão, Rio Grande do Sul, Brasil. Biota Neotrop. 13(4): 290-297 http://dx.doi.org/10.1590/ S1676-06032013000400026 (last access on 29/07/2019).

ZAR, J.H. 1999. Biostatistical Analysis. Prentice Hall, New Jersey.

ZIMMERMAN, B.L. \& BIERREGAARD, R.O. 1986. Relevance of the Equilibrium Theory of Island Biogeography and Species-Area Relations to Conservation with a Case from Amazonia. J. Biogeogr. 13(2):133-143.

ZUUR, A.F., IENO, E.N. \& ELPHICK, C.S. 2010. A protocol for data exploration to avoid common statistical problems. Methods Ecol. Evol. 1(1):3-14.

WELLS, K.D. 2007. The ecology and behavior of amphibians. Bibliovault OAI Repository, Chicago University Press.

WREGE, M.S., STEINMETZ, S., REISSER JUNIOR, C., ALMEIDA, I.R. DE. 2012. Atlas climático da Região Sul do Brasil: Estados do Paraná, Santa Catarina e Rio Grande do Sul. Colombo: Embrapa Florestas. Pelotas.

Received: $29 / 07 / 2020$

Accepted: 08/09/2020

Published online: 12/10/2020 